\title{
An Initial Study Of Industrial Area's Effects For The Air Pollution Through Rainwater In East Jakarta
}

\author{
Titia Izzati ${ }^{1}$, Wiwit Suprihatiningsih ${ }^{2}$, Woro Satuti ${ }^{3}$, Fuji Satryo Febrian ${ }^{3}$, \\ Martina Nur Rahayu ${ }^{3}$, Jerjer Rio Jenario ${ }^{3}$ \\ ${ }^{1}$ Industrial Engineering Program, Engineering Faculty, Mercu Buana University, 11650, Indonesia \\ ${ }^{2}$ Mechanical Engineering Program, Engineering Faculty, Mercu Buana University, 11650, Indonesia \\ ${ }^{3}$ Young Researcher Program, Mardiana and Youth Research Center, 13810, Indonesia
}

\begin{abstract}
This study aims to determine the level of acidity in the rainwater in the industrial area of East Jakarta. The research was done by using a multimeter (Waterproof Tester). With these tools, it can be seen $\mathrm{pH}$, $E C, T D S$, and temperature in the rainwater. The results shown that the rainwater in the area of East Jakarta tends to be normal because it is still in the average and standard. Although these areas are industrial areas, airports, and many transportation passes, the industrial area still have green places.
\end{abstract}

Keyword:industry, air pollution, rainwater, Jakarta

\section{Introduction}

Environmental pollution is the dispersal of chemicals with a certain level that can change the state of the balance of the recycling material, both the state structure and function, so that it can be annoying gaps in human life[1].One of the environmental pollution that often occurs today is the mass of air pollution[1,2]. Air pollution occurs when the composition of a substance or substances that exist in the air exceeded the specified threshold. The presence of chemicals that exceed the limits can be harmful to human health, and also can disrupt the lives of animals and plants[3,4]. With the onset of air pollution can also disrupt the climate (weather) resulting from human activity and technological advances mainly due to fuel combustion processindustry or motor vehicles, then it can lead to acid rain because of manykinds of gases produced and mixed with air as contaminants[5].

Chemicals that are air pollutants are carbon dioxide $\left(\mathrm{CO}_{2}\right)$, carbon monoxide $(\mathrm{CO})$, sulfur dioxide $\left(\mathrm{SO}_{2}\right)$, nitrogen oxide $\left(\mathrm{NO}_{2}\right)$, hydrocarbons, particulates and heavy metals[4]. In the modern age where the total population is increasing and more and more dense, to meet the needs of biological and technological advances, the activities that disrupt the balance of growth for recycled materials is increasing. To prevent or reduce or eliminate the consequences is too great influence of the environment caused by air pollution, it should be their self-awareness of each person to always take care of the environment and protecting the environment and also for the welfare of life, such as a green spot in the industrial area[6, 7]. In the other hand, the issues of the low education level for Indonesian and the high number of the social welfare in the society have to followed by the growth of the industrial area $[8,9]$.

Research the level of acidity in the rainwater in the area of East Jakarta in March 2016, serves to determine the propensity How $\mathrm{pH}$ (acidity level) of rain in the area east Jakarta.The information about theTDS value and EC values is also important to check the standard of air pollution in East Jakarta[10-12].

\subsection{Sampling}

\section{Research Methodology}

Sampling in the rain is done in the area of East Jakarta. B RGF Measurement of the acidity of rainwater is conducted every rain occurred in March 2016 using a measuring instrument that has been prepared namely TDS Meter (Water proof Tester).

\subsection{Test Samples}

Tests were conducted to test the temperature, $\mathrm{pH}, \mathrm{EC}$ and TDS in rainwater from random spost in some area of the industrial area of East Jakarta.

\section{Results and Discussion}

Measuring the level of the rainwater acidity of the industrial area east Jakarta is conducted in every rain occurred in March 2016, starting from 7 to 22 . The range of measurement is decidedby the high of the quantity of rain time (morning, afternoon, and night). 


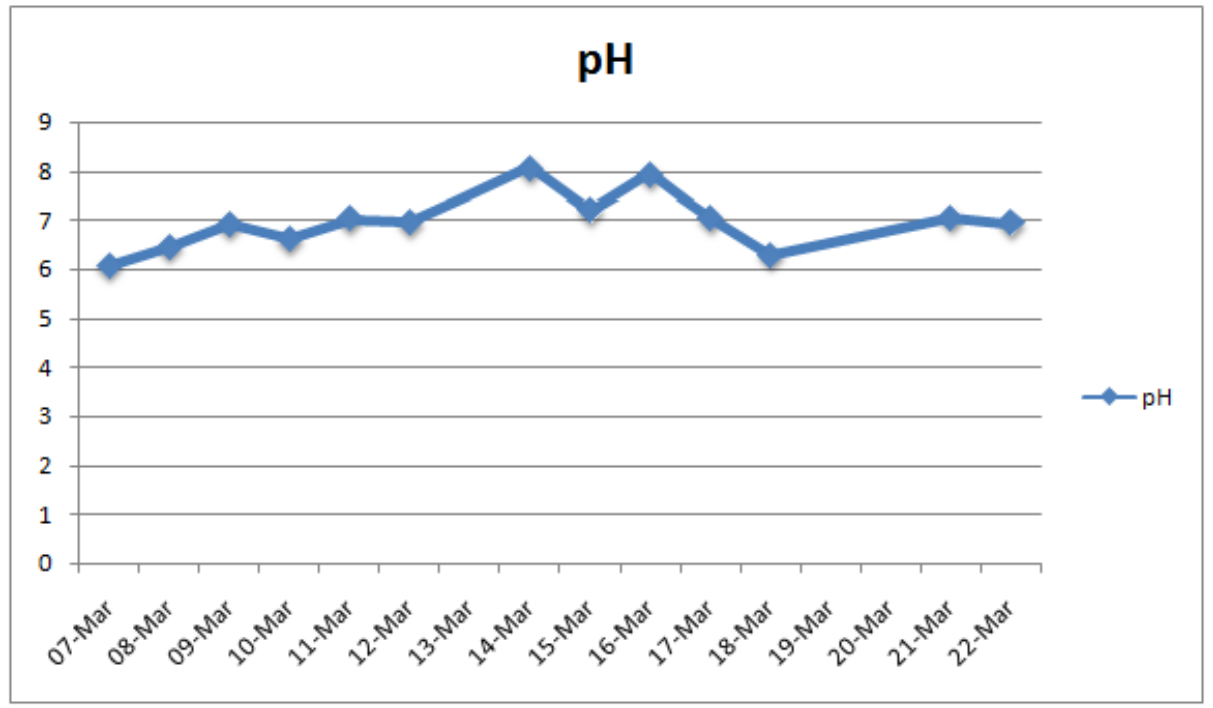

Figure 1.pH results

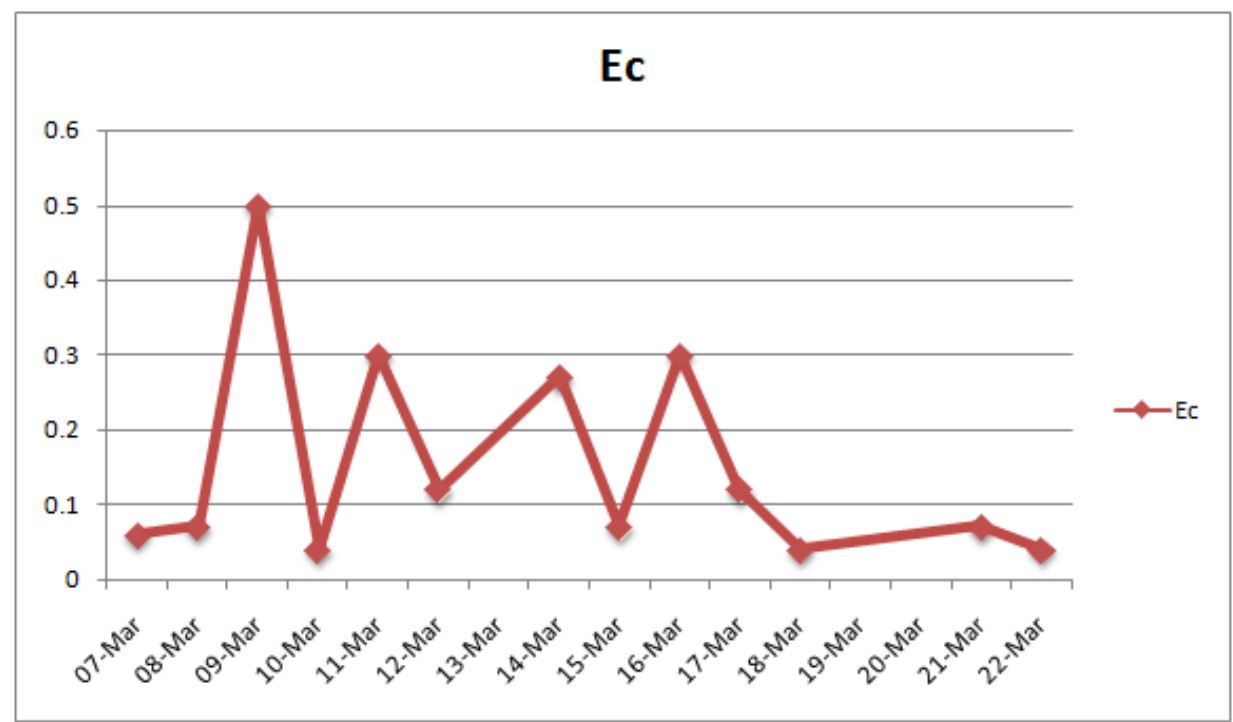

Figure 2. EC results

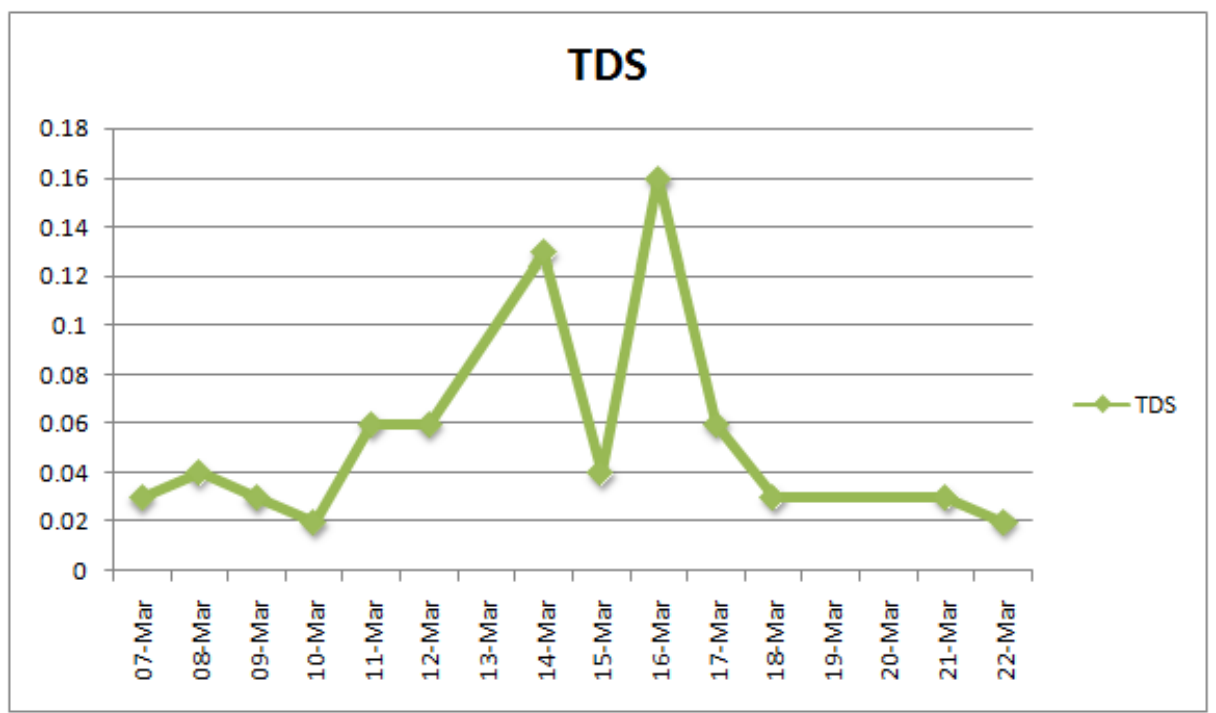

Figure 3. TDS results 


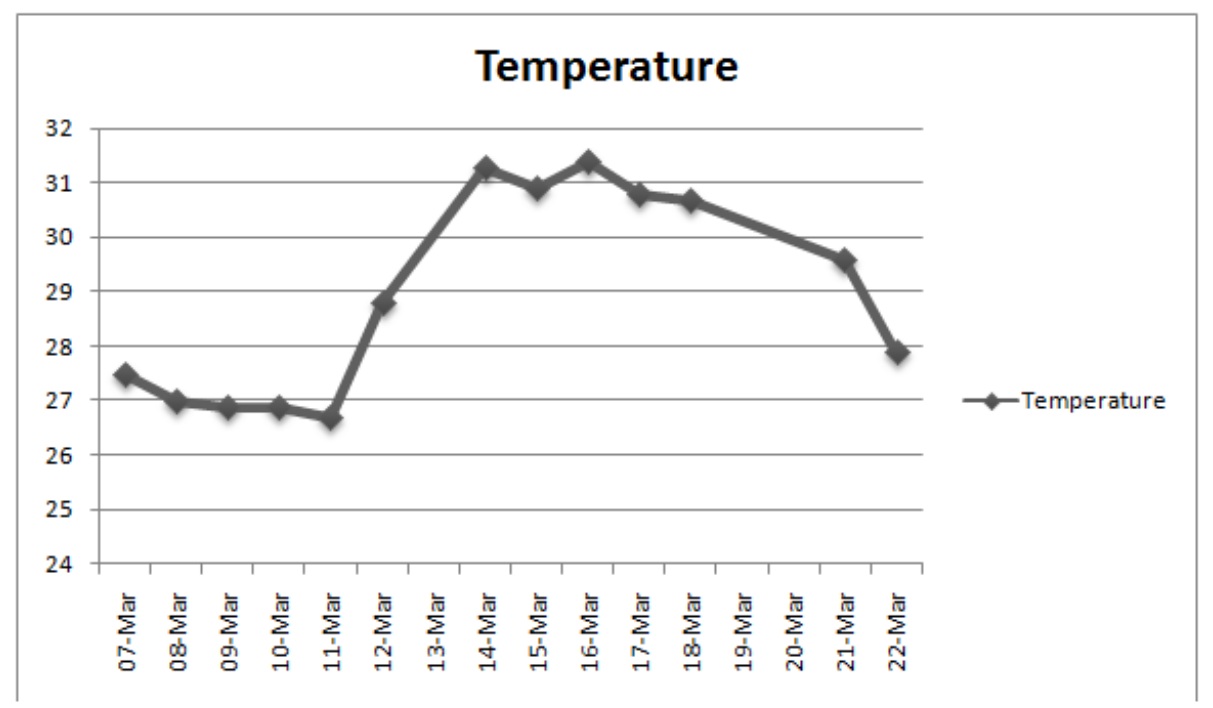

Figure 4. Temperature results

As shown in figure 1, the $\mathrm{pH}$ measurement graph shown that the rain water in the industrial area of East Jakarta tends to be normal because it has an average $\mathrm{pH}$ of rainwater on a daily basis. These data show the average of acidity is 6.54. Although in daily pHof rainwater in the area of East Jakarta has fluctuated values, the point of the $\mathrm{pH}$ tends to be normal, around 6.5 - 7.5. Analysis of the data will be analyzed based on outlet Indonesian Government regulations that the Minister of the Environment No. 115 of 2003 , concerningGuidelines for Determination of Water Quality Status with STORET methods[13, 14].

The figure 2 shows the measurement chart ofEC, it can be seen that the content of EC on the results obtained the data which is normal is 0.05 although the daily content of EC in the rain always increases from the onset of rain. But the content of EC for the availability of water for crops of at least 3. From these results, the availability of water for crops is safe enough for EC $<3[15,16]$.

The content of the temperature of the data is normal for the water temperature is too high despite almost. Where the normal water temperature is $<27$ degrees C. As shown in figure 4, the results obtained the average temperature is 27.7 degrees $\mathrm{C}$ so it is safe.

\section{- Geographical conditions}

Region East Jakarta area comprises $95 \%$ of the land and the remaining marshes or rice fields with an average height of $50 \mathrm{~m}$ above sea level and crossed by several river channels, among others: Cakung Drain, Ciliwung River, Malang River, Sunter, Cipinang.The geographical position is between 106049 '35' 'East Longitude and 060 10' 37 " South Latitude. Position equip the region with boundaries:

- Northern, Central Jakarta and North Jakarta

- West of South Jakarta

- To the South District. Tk.II area Bogor

- East side district. Tk.II Bekasi area.

East Jakarta municipality has some special characteristics, among others:

- Have some industrial areas, among others Pulo Gadung;

- Has some types of stem market, inter alia market Vegetables Kramat Jati, Cipinang Market;

- Have Halim Perdana Kusuma Airport;

- Have attractions include TMII and Lubang Buaya.

The observation of the level of acidity in rainwater in the area of East Jakarta, the rain water is normal, so the area of East Jakarta safe for occupancy. Although the area many industrial areas and airports are also many means of transportation but many places passed through reforestation in the area. Therefore elapsed areas in east Jakarta is safe from the level of acidity in rainwater.

\section{Conclusion}

The observation of the level of acidity in rainwater in the area of East Jakarta, the rain water is normal, so the area jakarta safe for occupancy. Although the area many industrial areas and airports are also many means of transportation but many places passed through reforestation in the area. Therefore elapsed areas in east Jakarta is safe from the level of acidity in rainwater. 


\section{References}

[1]. M.B. Hocking, Handbook of chemical technology and pollution control, Elsevier, 2016.

[2]. J. Stauffer, The water crisis: Constructing solutions to freshwater pollution, Routledge, 2013

[3]. W.Z. Tang, Physicochemical treatment of hazardous wastes, CRC Press, 2016.

[4]. Y. Qu, J. An, Y. He, J. Zheng, An overview of emissions of SO 2 and NO x and the long-range transport of oxidized sulfur and nitrogen pollutants in East Asia, Publisher, City, 2016.

[5]. E. Budiharjo, Kota Berwawasan Lingkungan, Alumni, 1993.

[6]. M.S. Purwanto, Manfaat dan Guna Pohon dan Hutan Kota, Publisher, City, 2012.

[7]. T. Izzati, Y. Poerwanti, Enhancing The Productivity And Multifunctionality Of Open Space Using Simple Techniques In Green Buildings, Publisher, City, 2014.

[8]. T. Izzati, P. Hastuti, I. Gunawan, E. Sukmawijaya, An Education Profile Of Indonesian Youth In 2009-2013, Publisher, City, 2015.

[9]. T. Izzati, P. Hastuti, I. Gunawan, E. Sukmawijaya, Social Welfare Programs For Young Society In Indonesia, Publisher, City, 2015.

[10]. B.P. Resosudarmo, L. Napitupulu, Health and economic impact of air pollution in Jakarta, Publisher, City, 2004.

[11]. N. Willoughby, H. Sangkoyo, B.O. Lakaseru, Beach litter: an increasing and changing problem for Indonesia, Publisher, City, 1997.

[12]. B. Ostro, Estimating health effects of air pollution: A methodology with an application to Jakarta, Publisher, City, 1994.

[13]. M.N.L. Hidup, Keputusan Menteri Negara Lingkungan Hidup No. 115 Tahun 2003 Tentang Pedoman Penentuan Status Mutu Air, in, Jakarta: Menteri Negara Lingkungan Hidup, 2003.

[14]. M. Situmorang, Kimia Lingkungan, Publisher, City, 2007.

[15]. L.D. Kesehatan, M. Miskin, Departemen Kesehatan Republik Indonesia, Publisher, City, 2005.

[16]. A. Ali, Kajian Kualitas Air dan Status Mutu Air Sungai Metro di Kecamatan Sukun Kota Malang, Publisher, City, 2013. 